(B. de Meillon, H. K. Munro), the biology of a nestliving Sarcophagid (A. Cuthbertson), studies of new Thysanoptera (C. Jacot-Guillarmod), descriptions of South African moths (A. J. T. Janse), the control of temperature and humidity in small cabinets (II. N. S. Immelman)' and finally on the general classification of insects (J. Omer-Cooper). The journal is excellently printed and illustrated, and the first volume, including also index, obituary notices and list of members of the Society, extends to 163 pages. It is obtainable from the Honorary Secretary of the Society, P.O. Box 103, Pretoria, South Africa, and from $\mathrm{N}$. V. Swets and Zeitlinger, Keizersgracht 471 , Amsterdam, Holland. The price of the volumo is El 2.s. 6d.

IT is announced in the Bee World that an AllIndia Bee-Keepers' Association has been founded with an official organ, the Indian Bee Journal, the first issue of which appeared in January 1939. Owing to various eauses, modern apiculture has an uphill journey in order to take its appropriate place in the scheme of Indian agriculture. The difficulties are being surmounted and the inauguration of the abovo Association and its Journal is likely to become an important factor in future progress. The address of the Association is Jeolikote, Naini Tal, U.P., India, and the annual subscription to tho Journal is 3 rupees for one year, and proportionately less for two or more years.

\section{Earthquakes during April I939}

Accondiva to the Central Seismological Bureau at Strasbourg there were 152 earthquakes each recorded at more than one observatory or experienced by people during the month of April. This was 52 moro than during March (Nature, June 10, p. 988). The greatest number recorded on any one day was on April 6, when 14 occurred, and the least number recorded on any one day was 2 on each of April 8, 9, 28 and 30 . The most important shocks during the month were probably those of April 1 (strength VIII) felt near Mostaganem in Algeria, April 18 at 6.23 G.C.T. in Chile (epicentre $27^{\circ} \mathrm{S}$, $70^{\circ} \mathrm{W}$. approx.), and that of April 30 felt at Guadalcanar and sereral other places in the Solomon Islands. The next most intense were the earthquakes of April 5 with epicentre near $20^{\circ} \mathrm{S} ., 168^{\circ} \mathrm{W}$., in the New Hebrides, April 21 at 4.29 G.C.T. (epicentro near Yeso), and April 23 at 16.23 G.C.T. (epicentre in the Atlantic near $1^{\circ} \mathrm{S} ., 17^{\circ} \mathrm{W}$.). Apart from these individual shocks there appears to have been a good deal of moderately intense seismological activity in Italy as earthquake shocks have been experienced at Livorno on more than one occasion, in the Frioul district and near Mont Amiata.

\section{British Standards for A.R.P. Requirements}

The Home Office Air Raid Precautions Department has arranged with the British Standards Institution to prepare and issued on its behalf a special A.R.P. series of British standards for air raid precautions purposes. The preparation of these standards will be under the control of a special advisory committee, and in accordance with the usual practice of the British Standards Institution will be carried out in the closest co-operation with Government departments and tho industry concerned. All communications relating to this work should be addressed to the British Standards Institution, 28 Victoria Street, Westminster, S.WV.1.

\section{Research in Pathology at Leeds}

Trie report for the years 1937 and 1938 of the Department of Pathology and Bacteriology of the University of Leeds, by Profs. Matthew Stewart and J. W. McLeod, has recently been issued. A summary of the routine examinations carried out is first given, followed by abstracts of the research work that has been done. This includes investigations on cases of silicosis and asbestosis, studies on the morbid anatomy and histology of chronic arthritis and its treatment with gold salts, and investigations on the morbid histology of diphtheria caused by the three types of the diphtheria bacillus. A report on cancer research is also contributed by Prof. R. D. Passey.

\section{Conference on Engineering Education and Training}

A Conference on Engineering Education and Training will be held at the Institution of Civil Engineers during February 6-8, 1940. Sir Clement Hindley, president-elect of the Institution, will preside over the Conference, which is being organized by a general committee representative of engineering institutions, universities, technical schools and colleges, engineering consultants, industrial organizations, Government departments and other interests. It is proposed to publish a number of papers, to be circulated in advance, which will form the basis of discussion at the technical sessions of the Conference. Inquiries should be addressed to the Secretary, Institution of Civil Engineers, Great George Street, London, S.TV.1.

\section{Two Large Sunspots}

Two large groups of sunspots were conspicuous on the sun's disk during the past week. The larger of these groups, in latitude $4^{\circ}$ south, appeared over the sun's east limb on July 3 and became a complex group with an area exceeding 1700 millionths of the sun's hemisphere. Its time of central meridian passage was July 9.3 U.T. The other group arose from a pair of tiny spots seen on July 4 in north latitude $6^{\circ}$. Shortly after its central meridian passage on July $8 \cdot 2$, it had reached an area of 1000 millionths.

\section{British Empire Cancer Campaign}

AT the seventy-first quarterly meeting of the Grand Council of the British Empire Cancer Cam. paign held on July 10, the following grants were approved : $£ \$ 00$ to Mount Vernon Hospital for the employment of Prof. F. Weigert for research on a special biochemical problem; $£ 495$ to the Strangeways Research Isaboratory, Cambridge, for the 
salary of its physicist, Dr. D. E. Lea, and $£ 400$ to Sir Robert Muir and Dr. P. R. Peacock for research to be carried out at the Glasgow Royal Cancer Hospital by Dr. Stephan Beck. This brings the total grants made to date by the Campaign for cancer research for the year 1939 to more than $£ 49,000$. The formation of a University of Cambridge Research Centre of the British Empire Cancer Campaign was approved. The initial Committee to supervise this Centre will consist of the Vice-Chancellor, Prof. H. R. Dean, Prof. J. A. Ryle, Sir Frederick Gowland Hopkins and Dr. Honor Fell, augmented later by other scientific workers at Cambridge. In future this Centre will co-ordinate all the cancer research being carried out at Cambridge and will itself initiate and direct research in the same way as the recently formed University of Oxford Research Centre of the Campaign. The Grand Council acceded to the request for affiliation from the Cancer Research Fund Committee (1934) of Northern Ireland, which now provides a link between the work of the Campaign and the cancer research being carried out at the University of Belfast and in Ulster generally. The following were elected members of Grand Council : Prof. J. A. Crowther (professor of physics in the University of Reading), Dr, H. T. Flint (director of physics at Westminster Hospital), Dr. R. W. Scarff (honorary secretary of the Scientific Committees of the Campaign) and Mr. D. G. Walker to represent the British Dental Association.

\section{The Colonial Service: Recent Appointments}

THe following appointments and promotions in the Colonial Service have recently been made: W. T. S. Brown, assistant conservator of forests, senior assistant conservator of forests, Gold Coast ; F. S. Danks, assistant conservator of forests, Cyprus, assistant conservator of Forests, British Guiana; H. W. Moor, senior assistant conservator of forests, divisional conservator of forests, Gold Coast ; G. M. Tolmie, assistant conservator of forests, senior assistant conservator of forests, Gold Coast ; B. E. Frayling, chief inspector of mines, Tanganyika Territory, chief inspector of mines, Nigeria; J. K. Cox, inspector of plants and produce, agricultural superintendent, Gold Coast.

\section{Announcements}

Dr. EMil Abderhaldex, professor of physiology at Halle, and Dr. Max Planck, professor of theoretical physics at Berlin, have been elected honorary members of the Société Philomathique of Paris.

Lord Horder has been elected president of the National Society for the Prevention of Venereal Diseases in succession to Sir Basil Peto, a foundermember and president since 1926.

Ax exhibition is being arranged at the Science Museum, South Kensington, in conjunction with the Royal Photographic Society and the photographic industry to illustrate the history of photography from the time of its inception in 1839 down to the present day. The exhibition is being opened by the Marquess of Salisbury on July 20, and will be open to the public on July 22 for five weeks.

A srmposium on "Growth and Development" to be held at North Truro, Massachusetts, during August 7-11 has been organized by the journal Growth. Grants towards the cost of the conference have been received from the Macy and Rockefeller Foundations. The topics for discussion, with their principal speakers, are : cell division and differentiation (Prof. W. H. Lewis, Prof. P. W. Gregory); genes and development (Prof. Curt Stern, Dr. C. H. Waddington); chemical factors (to be announced) (Dr. J. Needham) ; regeneration, organization (O. F. Schotte, Prof. E. W. Sinnott) ; concept of organism (Dr. J. H. Woodger). Further information can be obtained from Dr. Philip White, Rockefeller Institute for Medical Research, Princeton, New Jersey:

Tre People's League of Health has organized a scheme of clinical research to determino the influence of diet on expectant and nursing mothers in relation to maternal mortality and morbidity. Systematic observation and records are being collected at tho ten London hospitals which are co-operating with the Lcague in this research.

Acconding to the Central Dutch Office of Statistics, the average duration of life in men is at present 65.1 years and in women 66.4 years as compared with 38.4 and 40.7 during the period 1870-1879. The infant mortality, which was then as high as 22 per cent in males and 20 per cent in females, is to.day only 5 and 4 per cent respectively. During 18701879 only $7 \cdot 6$ per cent of Dutchmen reached the age of eighty years, whereas in 1931-1935 no less than 25 per cent reached that age. Holland has con. sequently the lowest mortality in Europe.

TrE Council of the Royal Society of Arts offers a prize of $£ 25$ under the Thomas Gray Memorial Trust for an invention, publication, diagram, etc., which is considered to be an advancement in the science or practice of navigation, proposed or invented in the period January 1, 1934 to December 31, 1939. Under the same trust, a prize of $£ 25$ for an essay on "The Carriage of Dangerous Goods by Sea" is offered. Further information can be obtained from the Secretary, Royal Society of Arts, John Street, Adelphi, London, IV.C.2.

A Researce scholarship of the value of $\$ 250$ per annum and tenable for two years has been founded by the IVrought Light Alloys Development Association to encourage and facilitate research in the application of light alloys to ship construction. The scholarship will be administered by a Committee of the Institution of Naval Architects and it is hoped to make the first award in September 1939. Further information can be obtained from the Secretary, Institution of Naval Architects, 10 Upper Belgrave Street, London, S.W.1. 